\title{
Factors Affected the Decline of Indonesian Coffee Competitiveness in Export Market During 2009-2018
}

\author{
Arief Darmawan ${ }^{1, *}$ Adhie Surachman ${ }^{2,}$ Ratih Hurriyati ${ }^{3,}$ Heny Hendrayati ${ }^{4}$ \\ ${ }^{I}$ Universitas Subang \\ ${ }^{2}$ Universitas Subang \\ ${ }^{3}$ School of Postgraduate Universitas Pendidikan Indonesia \\ ${ }^{4}$ School of Postgraduate Universitas Pendidikan Indonesia \\ *Corresponding author. Email: ariefdarmawan@unsub.ac.id
}

\begin{abstract}
This research is intended to develop model that is able to map the most related and affecting factors to the decline of Indonesian coffee export market share. This research used a quantitative approach based on time-series data. The analysis using time series techniques included variables that represented related factors and phenomena, to describe general patterns or trends, as evidenced by regression analysis. The produced model showed that all but one independent variable strongly affected the dynamic of Indonesian coffee exports. It turns out that the less coffee demands from major importing countries made the harvest being reallocated to developing Indonesia's local markets. This explains why the steady coffee harvest did not increase the export volume. The findings also revealed the importance to adopt GVC and sustainable (green) aspects to recover the decline.
\end{abstract}

Keywords: Indonesian Coffee, Export Market, Market Share.

\section{INTRODUCTION}

The adoption of GVC in ASEAN is the best and most thorough according to the OECD that linkages with multinational firms, in fostering their supply capacity and ability to innovate as well as facilitating the adoption of current product standards and certifications [1]. The less adoption of GVC by Indonesia agricultural MSME gives difficulties for exporting when environmental friendly/green products (SDGs) policies applied by G7 countries restricted many commodities to enter their market without proper green certifications [2]. Indonesian coffee is a golden product that becomes valuable export commodities, which makes Indonesia a leading world coffee producer [3]. Coffee commodities also have significant role as main livelihood for coffee producers that about $95 \%$ are MSMEs. However, there are set-backs on the Indonesian coffee market in 20092018 by the decline of its export market-share is almost forty percent [4] amidst the fact that the world coffee price and national coffee harvest fluctuating but steadily increasing. The decrease affected a lot on coffee exports from Indonesia that reduced by $30 \%$ in 2018 [5]. Not only that Indonesia lost potential income for its GDP from coffee export, but also in the same time the gap is filled by Vietnam which then becomes the second-largest coffee exporter in the world [6]. Though the cultivated land is only $45 \%$ of Indonesia, but it is able to produce three times more [7].

The purpose of this study is to create an analytical model that can map the relationships and measure the influence of the MSMEs' coffee producer on the growth of the coffee export value. The study is significant to understand the phenomena that the decrease of the coffee export is not in line with the volume of the coffee harvest, though fluctuated but keep growing steadily. The factors that are predicted to influence the export values are the increase/ decrease of coffee (harvest) production volume each year, the volume of coffee exports, world coffee prices (in USD), and MSME agricultural loans.

The analysis model used a multiple linear regression statistical test to obtain parametric scientific answers regarding the declining trend in the value of Indonesian coffee export during 2009-2018. In appraising the contribution of a sector to the value of export, many researchers tend to pay attention to productivity $[8,9]$, 
effect of exchange rates $[10,11]$ and human resources readiness $[12,13]$. While most researchers considered inflation rates as the most affecting factors [14]. Based on coffee commodities value chains, four factors were selected for mapping its relation and effects to the decline of Indonesia coffee export value [15]. Those factors that become independent variables are annual coffee harvest (95\% produced by MSMEs), coffee export volume, world coffee prices [16], and MSMEs agriculture loans [17].

\section{METHODS}

This research used a quantitative approach based on time-series data. Quantitative forecasting methods using time series were widely used for research objects that were fixed and not dynamic, and generally divided into two types of methods, namely causal and time series [18].

The analysis using time series techniques included variables that represented related factors and phenomena to describe general patterns or trends as evidenced by regression analysis [19]. The time series technique is an inexpensive quantitative method widely used in research to analyze classified past data based on reliable data sources (valid). Hence, the time series model is preferred and has been used in many applications such as Economic Forecasting, Budget Analysis, and Quality Control and Logistics Inventory Studies, and more [20].

\section{RESULTS AND DISCUSSION}

\subsection{Research Framework and Operational Variables}

A mapping model developed refers to the selected research variables presented in the figure 1, which illustrate strong relationship and influence on the growth of Indonesian coffee export values includes the affected factors (hypotheses).

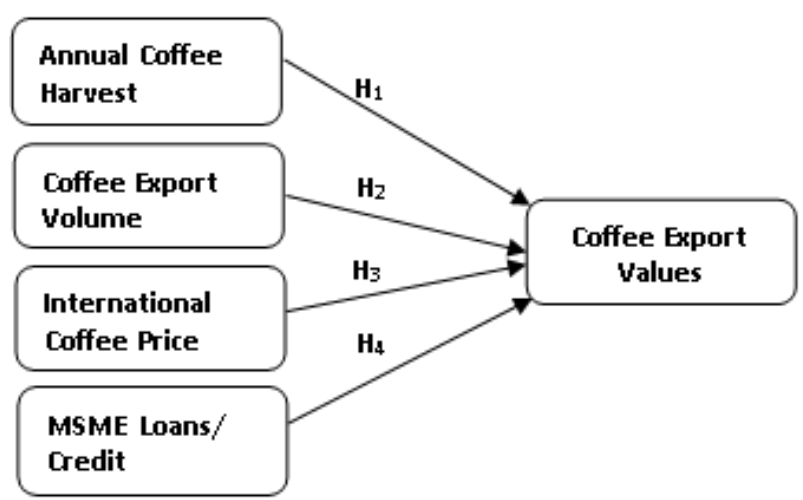

Figure 1. Research Framework.

These factors operationalized into research variables, as follow:
1) The dependent variable, namely the growth of the value of coffee exports during the period 2009-2018 with units of ten trillions of rupiah.

2) Independent variables, which can explain the dependent variable.

a) Indonesian annual coffee export value, during the period 2009-2018 with units of ten thousand of USD;

b) Coffee harvest volume, during the period 2009. 2018 with units of ten thousand of ton;

c) International coffee price, during the period 2009-2018 in Cent USD/pound; and

d) UMKM agricultural loans, during the period 2009-2018 with units of ten trillion rupiahs.

e) The proposed four research hypotheses according to the results of the operationalization of the variables include:

H1: Increased coffee harvest of MSME production affects the increase of Indonesian coffee exports' value.

H2: The development of UMKM coffee export volume affects the increase of Indonesian coffee exports' value.

H3: The development of world coffee prices affects the increase of Indonesian coffee exports' value.

H4: The development of MSME investment loans affects productivity and contributes positively to the increase Indonesian coffee exports' value.

The type of secondary data used was time-series data, in the form of statistical data for the last ten years of the 2009-2018 period, which includes the value of Indonesian coffee exports as the dependent variable. The four influential factors become independent variables. Data collection was carried out by browsing at each publisher's institution site, by agreeing to the provisions of public data disclosure and using open-source data for non-commercial purposes. The collected data then were arranged into groups according to the type and period. This study utilized quantitative analysis to map the relationships and effects between the dependent and independent variables using multiple linear regression analysis. Equation (1) is a multiple linear regression.

$$
\mathrm{Y}=\alpha+\beta_{\cap=} \beta_{1} \mathrm{X}_{1}+\beta_{2} \mathrm{X}_{2}+\beta_{3} \mathrm{X}_{3}+\beta_{4} \mathrm{X}_{4}+\ldots
$$

Where:

$Y=$ Dependent variable, which is Indonesia annual coffee export value (ten trillion $\mathrm{Rp}$ )

$\alpha=$ Constant

$\beta=$ Regression Coefficient

$X_{1}=$ Coffee Harvest Volume (ten thousand Ton) 
$X_{2}=$ Coffee Export Volume (ten thousand Ton)

$X_{3}=$ International Coffee Price (USD)

$X_{4}=$ MSMEs Agricultural Loans (ten trillion Rp)

$\varepsilon=$ Error

The stages of multiple linear regression analysis carried out include:

1) Testing classic assumptions

a) Normality test, using the Kolmogorov-Smirnov test, with the Skewness and Kurtosis tests, as well as plot data distribution charts;

b) Autocorrelation test, to find out there is no autocorrelation between the linearity test and the Durbin Watson coefficient;

c) Multicollinearity test, by looking at the value of tolerance and VIF; and

d) Heteroscedasticity test, using the Glejser test by checking the significance of $t$, as well as the results of the scattered-data plot.

2) Hypothesis Statistics Test

a) The research hypothesis test carried out by referring to the statistical testing of the regression model parameters ( $t$-test and $F$ test) and testing the coefficient of the determinant ( $R$ Square).

b) The determinant coefficient, used to check the magnitude of $\mathrm{R}$ Square, which explains the ability of all independent variables to explain the dependent variable.

c) Test F (Simultaneous Test), used to test whether the independent variables together have a significant influence on the dependent variable. The parameters of the test results at $\alpha=5 \%$, if $\mathrm{F}$ count $\leq \mathrm{F}$ table or the significance of test $\mathrm{F}>$ 0.05 then Ho can be accepted, meaning that the independent variables tested simultaneously do not affect the dependent variable.

d) Test $\mathrm{t}$ (Partial Test), to test whether the independent variables partially (individually) have a significant influence on the dependent variable. The parameters of the test results at $\alpha$ $=5 \%$, if $\mathrm{t}$-test $<\mathrm{t}$ table or the significance value of t-test > 0.05 then Ho can be accepted, meaning that based on the test results, the independent variable partially does not influence the dependent variable.

\subsection{Description of Statistical Analysis}

Based on the results of multiple linear regression using SPSS version 22, the statistical analysis results are as follows:
1) The determinant coefficient (B)

The linear regression obtained an adjusted R Square value of 0.665 , which means that the independent variable can explain the variance of the dependent variable by $66.5 \%$, while the other $33.5 \%$ explained by other factors. The model summary can be seen in table 1 .

Table 1. Model Summary

\begin{tabular}{|l|l|l|l|l|}
\hline Model & R & R Square & $\begin{array}{c}\text { Adjusted R } \\
\text { Square }\end{array}$ & $\begin{array}{c}\text { Durbin- } \\
\text { Watson }\end{array}$ \\
\hline 1 & $.902^{\mathrm{a}}$ & .814 & .665 & 2.107 \\
\hline
\end{tabular}

Based on table 1, the research model is reliable to predict the relationship between the growths of coffee export value as the dependent variable to the development of independent variables (coffee harvest volume, coffee export volume, export prices, and MSME agricultural loan) used in the model.

2) F Test Results (Simultaneous Test)

From the table 2, for a $5 \%$ confidence level, the calculated $F$ value of 5.461 obtained with a significance of 0.045 . Comparing with the table $\mathrm{F}$ value where $\mathrm{df} 1=$ $\mathrm{k}-1=3$ and $\mathrm{df} 2=\mathrm{n}-\mathrm{k}=10-4=6$, the $\mathrm{F}$ table value of 4.76 is obtained. Because F count $>\mathrm{F}$ table and significance of the F test $0.045<0.05$ then Ho is rejected, meaning that the tested independent variables simultaneously influenced the dependent variable.

Table 2.Anova

\begin{tabular}{|l|l|l|l|l|}
\hline \multicolumn{2}{|c|}{ Model } & \multicolumn{1}{c|}{ Df } & \multicolumn{1}{c|}{ F } & Sig. \\
\hline \multirow{4}{*}{1} & Regression & 4 & 5.461 & $\mathbf{0 4 5}^{\mathbf{b}}$ \\
\cline { 2 - 6 } & Residual & 5 & & \\
\cline { 2 - 4 } & Total & 9 & & \\
\hline
\end{tabular}

3) t-Test Results (Partial Test)

From the table 3 , for a $5 \%$ confidence level, it was obtained the constant value of the regression equation (B), t-test, and significance for each independent variable. T-test analysis compares the t-test of each independent variable with the $t$ table. $\mathrm{T}$ table value is obtained from $t$ table with the formula: $t$ table $=(\alpha / 2 ; n$ $\mathrm{k}-1$ or df residual value), then $\mathrm{t}$ table $(0.25 ; 5)$ is obtained with a value of 2.571 .

Table 3. Coefficients

\begin{tabular}{|c|c|c|c|c|c|}
\hline & \multirow[t]{2}{*}{ Model } & \multicolumn{2}{|c|}{$\begin{array}{c}\text { Unstandardized } \\
\text { Coefficients }\end{array}$} & \multirow[t]{2}{*}{$\mathbf{t}$} & \multirow[t]{2}{*}{ Sig. } \\
\hline & & $\boldsymbol{B}$ & Std. Error & & \\
\hline \multirow[t]{5}{*}{1} & (Constant) & -87.496 & 108.021 & -.810 & .455 \\
\hline & Harvest & .321 & 1.326 & .242 & .819 \\
\hline & Export & 2.115 & .513 & 4.126 & .009 \\
\hline & Price & 25.485 & 9.075 & 2.808 & .038 \\
\hline & Loan & 5.428 & 1.635 & 3.320 & .021 \\
\hline
\end{tabular}

Hence, referring to the t-test results for each independent variable, the analysis is as follows:

- Harvest volume, as an independent variable (H1), obtains t-test of $0.242<\mathrm{t}$ table 2.571 and 
significance value of t-test $0.819<0.05$ then Ho is accepted, meaning based on test results, Harvest variable does not influence the export value variable.

- Export volume, as an independent variable (H2), obtains t-test of $4.126>\mathrm{t}$ table 2.571 and a significance value of t-test of $0.009<0.05$ then Ho is rejected, meaning that based on test results, the export volume variable partially influences the export value variable.

- International Coffee Price, as an independent variable (H3), obtains t-test value of $2.808>\mathrm{t}$ table 2.571 and significance value of t-test $0.038<0.05$ then Ho is rejected, meaning based on the test results, the variable coffee price partially influences the variable export value.

MSME agriculture loans, as the independent variable (H4), obtains t-test $3.320>$ t table 2.571 and significance value t-test $0.021<0.05$ then Ho is rejected, meaning based on the test results, the MSME Loan variable partially influences the export value variable.

\subsection{Interpretation of Statistical Analysis}

Based on the results of the statistical analysis description, the equation of the multiple linear regression referring to obtained determinant coefficients are as seen in (2).

$Y=-87,496+0,321 \quad X 1+2,115 \quad X 2+25,485 \quad X 3+5,428 \quad X 4$

Referring to the above equation and the results of the statistical test significance, it is believed that an increase in coffee export volume, international coffee prices (in USD) and MSME loans, either jointly or individually (partially), contribute positively and significantly to the increase and decrease value of coffee export in the 20092018 period. Regardless of having a positive relationship, surprisingly coffee harvest did not affect nor had a meaningful contribution to the increase of coffee export value.

Despite quite stable cultivation areas and stagnant productivity, during 2009-2018 the coffee production was slightly increasing. However, at the same time, the export volume was significantly decreasing by $30 \%$ in 2018 (from 416 tons in 2017 to 294 tons in 2018). Aside from the reduced potential income of Indonesia's GDP from coffee export, the most important fact is $95 \%$ of landowners and farmers are MSMEs.

The decline in coffee exports in the long term possibly causing a collapse in coffee prices at the farmer level. Without proper and systematic solutions, the phenomena can lead to negative economic impacts for the coffee-producer green MSMEs [21]. According to the USDA-GAIN report, Indonesian coffee consumption during 2018-2019 increased to 4.3 million coffee bags (a bag@60 kg), based on high consumer demands for fresh roasted, soluble, and Ready to Drink (RTD) products. While consumption for 2019-2020 production year is forecast for 4.9 million bags based on continued high consumer demand [22]. The trend explains the significant increase in MSMEs' agricultural loans from 2000-2018. In spite of the fact that increasing loans have the same directions with the export values, the loan mostly utilized for cultivation aspects (productions) rather than to create added values from post-production in terms of roasting, branding, packaging, marketing, and distributing [23].

\section{CONCLUSIONS}

The research model has successfully answered the question of the influence of the coffee harvest (production) to the value of exports in the 2009-2018 period. Less coffee demands of major importing countries creates booming on domestic coffee demand. The adoption of the SDGs principles by the global industry, such as Nestle and Starbucks, should create new marketing channels. Likewise, the shift in consumer behavior to have more concerns with environmentally friendly products is an opportunity not a burden to coffee export. Other coffee producer country like Viet Nam, implement GVC principles in terms of sustainability certification from green NGOs like UTZ and Fairtrade. The certification assists coffee-producers MSMEs to improve their coffee competitiveness in global market.

\section{ACKNOWLEDGMENT}

The authors express their utmost gratitude to the School of Postgraduates UPI for the opportunity to present the paper. In particular to the management department's lecturers who has kindly provided valuable inputs and discussion.

\section{REFERENCES}

[1] M. Wermelinger and I. Mantovani, "Integrating Southeast Asian SMEs in global value chainsenabling linkages with foreign investors," Geneva, 2019.

[2] R. Takahashi, Y. Todo, and Y. Funaki, "How can we motivate consumers to purchase certified forest coffee? Evidence from a laboratory randomized experiment using eye-trackers," Ecological Economics, vol. 150, pp. 107-121, October, 2018, doi: 10.1016/j.ecolecon.2018.04.010.

[3] M. Purnamasari, W-C. Huang, and N. Hanani, "Competitiveness of Indonesian coffee on the world market: Using selected indicators", 2013. [Online] Available:

http://nuhfil.lecture.ub.ac.id/?s=Competitiveness+o $\mathrm{f}+$ Indonesia+Coffee+on+The+World+Market+Usin $\mathrm{g}+$ selected+indicators 
[4] TPSA, "An analysis of the global value chain for Indonesian coffee exports," Jakarta, 2018.

[5] J.G.P. Bray, "Institutional environments and the livelihood impacts of voluntary sustainability standards: A village-based analysis from southern Sumatra's coffee sector," Singapore J. of Tropical Geography, vol. 40, pp. 291-311, 2019, doi; 10.1111/sjtg.12275.

[6] T.T. H. Nhung, N.T.L. Anh, and C.P. Nga, "Vietnam's participation in The Global Coffee Value Chain," International J. of Economics, Commerce and Management, United Kingdom, vol. 7, no. 12, pp. 440-456 2019.

[7] J. Sachs, K.Y. Cordes, J. Rising, P. Toledano, and N. Maennling, "Ensuring economic viability and sustainability of coffee production," District of Columbia, 2019.

[8] A.A. Ogundipe, O. Adu, O.M. Ogundipe, and A.J. Asaleye, "Macroeconomic impact of agricultural commodity price volatility in Nigeria," The Open Agriculture J., vol. 13, no. 1, pp. 162-174, 2019, doi: $10.2174 / 1874331501913010162$.

[9] R.P.I.R. Prasanna, J.M.S.B. Jayasundara, S.K.N. Gamage, E.M.S. Ekanayake, P.S.K. Rajapakshe, and G.A.K.N.J. Abeyrathne, "Sustainability of SMEs in the competition: A systemic review on technological challenges and SME performance," J. of Open Innovation: Technology, Market, and Complexity, vol. 5, no. 4, pp. 1-18, 2019, doi: 10.3390/joitmc5040100.

[10] G. Kala, R. Masbar, and S. Syahnur, "The effect of exchange rate, inflation, capital and labor force on economic growth in Indonesia," J. Ekonomi dan Kebijakan Publik Indonesia, vol. 5, no. 1, pp. 35-50, 2018.

[11]H. Şen, A. Kaya, S. Kaptan, and M. Cömert, "Interest rates, inflation, and exchange rates in fragile EMEs: A fresh look at the long-run interrelationships". J. of International Trade and Economic Development, vol. 29, no. 3, pp. 289-318, 2020, doi: 10.1080/09638199.2019.1663441.

[12]H. Şen, A. Kaya, S. Kaptan, and M. Cömert, "Interest rates, inflation, and exchange rates in fragile EMEs: A fresh look at the long-run interrelationships". J. of International Trade and Economic Development, vol. 29, no. 3, pp. 289-318, 2020, doi: 10.1080/09638199.2019.1663441.

[13] L.H. Thanh, L.T. Nhat, H.N. Dang, T.M.H. Ho, and P. Lebailly, "One Village One Product (OVOP)-A rural development strategy and the early adaption in
Vietnam," the Case of Quang Ninh Province. Sustainability (Switzerland), vol. 10, no. 12, 2018, doi: 10.3390/su10124485.

[14] S. Blinov, "Inflation and economic growth," J. of Economics Library, 4(2), 227-237, 2017.

[15] Nsabimana, and W.T. Tirkaso, "Examining coffee export performance in Eastern and Southern African countries: do bilateral trade relations matter?," Agrekon, vol. 59, no. 1, pp. 46-64, 2020, doi: 10.1080/03031853.2019.1631864.

[16] S. Hadi, D.B. Hakim, and T. Novianti, "Analysis of competitiveness and threshold price transmission of Indonesian coffee in importing countries," International J. of Scientific Research in Science, Engineering and Technology, vol. 8, no. 1, pp. 5162, 2019, doi: 10.32628/ijsrset196119.

[17]S. Arango-Aramburo, Y. Acevedo, and J. Sonnemans, "The influence of the strength of financial institutions and the investment production delay on commodity price cycles: A framed field experiment with coffee farmers in Colombia," Economist (Netherlands), vol. 167, no. 4, pp. $347-$ 358, 2019, doi: 10.1007/s10645-019-09343-z.

[18] K.C. Green and J.S. Armstrong, "Demand forecasting: evidence-based methods," SSRN Electronic J., vol. 165, pp. 1-27, October, 2012. https://doi.org/10.2139/ssrn.3063308

[19]S. Benkachcha, J. Benhra, and H. El Hassani, "Seasonal time series forecasting models based on artificial neural network," International J. of Computer Applications, vol. 116, no. 20, pp. 9-14, 2015.

[20] V. Gosasang, W. Chandraprakaikul, and S. Kiattisin, "A comparison of traditional and neural networks forecasting techniques for container throughput at Bangkok port," Asian J. of Shipping and Logistics, vol. 27, no. 3, pp. 463-482, 2011, doi: $10.1016 / \mathrm{S} 2092-5212(11) 80022-2$.

[21] World Bank, "Commodity markets outlook 2018- oil exporters: policies and challenges (vol. 1)," 2018. doi: 10.1017/CBO9781107415324.004.

[22] G. Mcdonald, "GAIN Report - Indonesia Coffee Annual Report," 2019.

[23]P. Behuria, "The domestic political economy of upgrading in global value chains: how politics shapes pathways for upgrading in Rwanda's coffee sector," Review of International Political Economy, vol. 27, no. 2, pp. 348-376, 2020, doi: 10.1080/09692290.2019.1625803. 